\title{
The Jinniu mines and the confusions of Qing sources on silver mining
}

Les mines de Jinniu et les imprécisions systématiques des sources officielles sur l'extraction de l'argent dans la Chine des Qing

\section{Nanny Kim and Yuda Yang}

\section{OpenEdition}

Journals

Electronic version

URL: https://journals.openedition.org/artefact/2028

DOI: $10.4000 /$ artefact.2028

ISSN: 2606-9245

\section{Publisher:}

Association Artefact. Techniques histoire et sciences humaines, Presses universitaires du Midi

\section{Printed version}

Date of publication: 6 December 2018

Number of pages: 111-139

ISBN: 978-2-8107-0595-5

ISSN: $2273-0753$

\section{Electronic reference}

Nanny Kim and Yuda Yang, "The Jinniu mines and the confusions of Qing sources on silver mining", Artefact [Online], 8| 2018, Online since 21 June 2019, connection on 21 September 2021. URL: http:// journals.openedition.org/artefact/2028 ; DOI: https://doi.org/10.4000/artefact.2028

\section{c) (i) $\Theta$}

Artefact, Techniques, histoire et sciences humaines est mise à disposition selon les termes de la Licence Creative Commons Attribution - Pas d'Utilisation Commerciale - Pas de Modification 4.0 International. 


\title{
The Jinniu mines and the confusions of Qing sources on silver mining
}

\author{
Nanny Kim et Yuda Yang
}

\section{Abstract}

Silver served as an unminted money for all larger transactions in late imperial China, yet historical sources on silver mining are scarce and unsatisfactory. While we know that the most important silver mines were located in Yunnan province and adjoining regions since the Yuan period, official records suggest very modest outputs that moreover declined steadily fell from through the Ming and Qing periods. This article analyses records and actual conditions on site with a focus on a specific mine that is comparatively well-documented as well as datable and provided particularly good conditions for fieldwork. Drawing on fieldwork on the remains on site and on local oral histories, an exemplary assessment of the fully official and the private records becomes possible. The discussion expands the focus to the known major silver mines in the regions, revealing the massive omissions in the official records. The presented research demonstrates the limited use of official government records and proposes an approach based on actual sites, material remains and oral histories for a new study of the history of late imperial silver mining.

\section{Keywords}

Southwest China, silver mining, Qing period, sources, official and unofficial records, material remains, fieldwork, historical methodology

99 Nanny Kim et Yuda Yang, « The Jinniu mines and the confusions of Qing sources on silver mining », Artefact, 8, 2018, p. 111-139. 


\section{Les mines de Jinniu et les imprécisions systématiques des sources officielles sur l'extraction de l'argent dans la Chine des Qing}

\section{Résumé}

Dans la Chine de lépoque de l'empire tardive (1368-1911), l'argent servait de monnaie non frappée pour toutes les transactions importantes. Or les archives sur les mines d'argent sont extrêmement clairsemées et sujet à caution. Depuis la période des Yuan (1279-1368), les mines les plus importantes se situaient dans et autour de la province de Yunnan ; leur productivité, d'après les archives officielles, était très modeste et a continué de décliner au cours des périodes Ming et Qing. Cet article présente une analyse des sources en s'appuyant sur une étude de cas d'une mine comparativement bien documentée, datable et présentant des conditions excellentes pour le travail de terrain. En menant des recherches sur les vestiges matériels et l'histoire orale, une réappréciation des archives officielles et privées devient possible. La discussion élargit la perspective sur les mines d'argent identifiées dans la région du nord-est de Yunnan, révélant des lacunes majeures dans les archives officielles. Cette étude met en évidence les limites des archives officielles et propose une méthode fondée sur des sites existants, des vestiges matériels et des traditions orales pour une nouvelle histoire des exploitations minières d'argent en Chine à l'époque de l'empire tardive.

\section{Mots-clés}

sud-ouest de la Chine, période Qing, mines d'argent, sources officielles et non officielles, vestiges matériels, travail de terrain, méthodologie historique 


\section{Introduction}

Some forty important and at least a hundred lesser minor silver mines were worked across Yunnan province during the Qing (1644-1912) period. ${ }^{1}$ We know far too little about most of these mines. Local gazetteers and other official sources rarely record more than the name, date of the opening and sometimes the closure, together with the current tax quota and occasionally earlier rates. For the majority of sites, no other materials are available. The scarcity of sources is an obstacle to research, and it is compounded by their unreliability.

In his authoritative reconstruction of silver outputs of Yunnan on the basis of tax records, Quan Hansheng reached an estimate of annual outputs in the range of 17.02 tons (460,000 liang) for the Qing period. He cautioned, however, that his figures omitted productive borderland mines, specifically mentioning a mine in the Dashan area of Burma, from which at some point about 1760 annually 37 tons, or "over 1 million liang" entered the Qing empire, and the Songxing (宋星 or 送星) mines in Vietnam, from which about 64 tons, or a recorded 2 million liang, were annually imported, probably in the 1830 s and possibly earlier. The concrete examples indicate that the reconstruction was incomplete. Moreover, the high productivity of certain borderland mines compared to the modest outputs of mines in the interior of the empire reflected in tax reports would suggest that the majority of Chinese miners worked outside China and hence raises doubts on the reliability of the data. ${ }^{2}$

\footnotetext{
1. Weighed estimate based on data from Yuan Ruan 阮元, Yunnan tongzhi 雲南通志 (Gazetteer of Yunnan), 1835, Kunming, Yunnan daxue chubanshe, reprint 2001, juan 9, which contains a list of mines with tax rates laid down by the central government; Guangyu QIN 秦光玉, Xinzuan yunnan tongzhi 新纂雲南通志 (Newly-compiled gazetteer of Yunnan), Kunming, 1949, juan 64, compiled from materials of the Qing and down to about 1930; and ongoing research by the authors on the sites of important mines.

2. Hansheng QUAN 全漢昇, “Ming-Qing shidai Yunnan de yinke yu yinchan'e” 明清時代雲南 的銀課與銀產額 (Silver taxes and silver output of Yunnan in the Ming and Qing periods), Xinya xuebao 新亞學報 vol. 11, $\mathrm{n}^{\circ}$ 1, 1976, p. 61-88. His sources for the two borderland mines are ZHAO Yi 赵翼, Yanbao zaji 簷曝杂记 (Scattered notes), Beijing, Zhonghua shuju, reprint 1982, and the Veritable Records of the Ngyuen Dynasty. Yang Yuda identified the mines in the Dashan area as the Bolong/Bawdwin 波竜 Mines. See Yuda YANG, "Silver mines in frontier zones: Chinese mining communities along the south-western borders of the Qing empire”, Nanny KIM (transl.), in Nanny KIm and Nagase-Reimer Keiko eds., Mining, monies and culture in early modern societies: East Asian and global perspectives, Leiden, Brill, 2013, p. 94-95.
} 
In an ongoing project on late imperial silver mines in the far southwest, the authors turned to sources outside the traditional written records, studying remains on site, industrial records, and oral histories. In the course of our work on some thirty sites, we have found divergences between records and conditions found on site to be greater than expected. This is most obvious for sites that according to the records were minor mines or were not even registered, but where huge slag dumps document massive exploitation. ${ }^{3}$

This article presents an analysis of the sources and develops a research strategy for a re-assessment of the scope of silver mining. It begins by a case study of the Jinniu 金牛 mines in north-eastern Yunnan. We chose this site because it is a rare case in which we have two conflicting records. Moreover, fieldwork conditions are favourable because exploitation has not been revived since the end of historic mining in the early $20^{\text {th }}$ century. Based on the assessment of the Qing records on the Jinniu mines, the exploration is widened to the five known important mines in the area.

The discussion of the records in conjunction with the reconstruction of mining at specific sites, contributes to the assessment of the sources and the understanding of their context of production as well as to the concrete history of mines. The results concerning the reliability of the fully official records are not encouraging. At the same time, however, the shift from the general regional perspective on mining to research on the basis of actual sites opens up a concrete and fruitful perspective with tangible results.

\section{The official records}

Yunnan province, where the largest and most productive mines were located, maintained a mining administration. The formalization of this administrative structure occurred in the early $18^{\text {th }}$ century following a relaxation of the initially highly restrictive mining policy established by the early Qing emperors. The catalyst in this change was the conviction of the imperial government that the minting of copper-based cash coins was a core sovereign task of the state and that the constant supply with coins had to be maintained even when the supply of copper from Japan

3. Yuda YANG and Nanny KIm, "Overlooked silver flows: Slag dumps and outputs of silver mines in the southwestern borderlands of China, fifteenth to nineteenth centuries", Harvard Journal of Asian Studies (submitted). 
became difficult. With the shift to domestic resources, the Qing government established administrative structures for promoting and controlling copper mines in Yunnan. A system of licensing, tax collection and supervision presumably had been in existence before, but it was only with the setting up of the formal structures of the "copper administration" that mining matters came to be reflected in the government documentation on the provincial and imperial levels. The mining administration was not an independent institution but a set of tasks added to the existing responsibilities of provincial and local officials. Considerable, though mostly sub-bureaucratic structures definitely existed, but these remain undocumented, since no provincial or local archives survived. Our sources are the published guidelines and communications with the central government. These comprise budgeting regulations, inventories of licensed mines, and some general information on processes and products. ${ }^{4}$

The core records for this investigation are excerpts of tax records that were included as lists of licensed mines in provincial gazetteers, and occasional reports on the opening, closure or on adjustments of taxation that are quotes in memorials submitted to the emperor. ${ }^{5}$ The most comprehensive text is a compendium of the Yunnan mining administration that was compiled by Wu Qijun 吳其濬 (1789-1847) and is entitled Illustrated Account of the Mines of Yunnan and was printed in 1844. The book is the core source on copper and silver mining. ${ }^{6}$

The information on specific sites usually consists of the name of the mine, taxation regulations, and an annual tax quota or the statement that no fixed quota was laid down. The most extensive entries include to the year of the official opening of the mine, the year of closure, when applicable, adjustments of the tax quota, and for affiliated mines the main mine. The recorded regulations obviously served budgeting purposes.

4. On copper mining and monetary policy, see Hans Ulrich Vogel, "Chinese central monetary policy, 1644-1800", Late Imperial China, vol. 8, n², 1987, p. 1-52.

5. Provincial gazetteers were compiled in 1763 and 1835, documents of the central government are excerpted in the Veritable Records of the Qing (Daqing shilu 大清實錄) and the Statutes and Regulations of the Qing (Daqing huidian 大清會典). These resources have been digitized as full-text databases by Erudition, Beijing, and by Shutong, Beijing.

6. Qijun Wu 吴其浚, Diannan kuangchan tulue 滇南矿厂图略, 1844, Shanghai guji chubanshe, Shanghai, reprint 2002. 
The provincial gazetteer of 1736 lists 16 silver mines, the edition of 1835 records 19 operating and 19 mines that were no longer in operation. The mining compendium of 1844 records 19 mines in operation, adding seven branch mines not previously listed. Consistency within the three sources is relatively high, but not complete. All sites recorded in the Gazetteer of 1736 appear in the two $19^{\text {th }}$ century texts, however the latter include several sites as formerly in operation that do not appear in the former. The 19 mines listed in the works of 1835 and 1844 are the same, though ordered differently, while the branch mines added in the compendium are not otherwise known. The recorded tax rate varies slightly, ranging about $16-20 \%$ of the output. Taxation reflects a wide range in productivity. The highest recorded tax rate applied to the Gejiu 箇舊 mines in southern Yunnan and amounted to 33,613.78 liang in the early $18^{\text {th }}$ century, while the lowest applied to Tugeci 土革喇 and was merely $1.5 \mathrm{liang}^{7}$. By the early $19^{\text {th }}$ century, all fixed tax rates had been adjusted downwards. By 1829, Gejiu reported 2360 liang, and the Lema 樂馬 mines in northeastern Yunnan now fulfilling the highest quota of 6353 liang. Assuming that the rate was in fact collected at the stipulated $16 \%$, the tax quotas reflect outputs between a maximum of some 7.8 tons in 1835 and 1.5 ton in 1844 , and a minimum of $3.5 \mathrm{~kg}$ for the smallest mine. The records suggest sizeable outputs for the largest mines and a steady overall downturn in productivity.

\section{The Jinniu mines in the fully official records}

Records on the Jinniu mines, literally the "golden ox", are found in four $19^{\text {th }}$ century sources. Neither the mines nor the place name are mentioned in the provincial or local gazetteers of the $18^{\text {th }}$ century ${ }^{8}$. The earliest record appears in the provincial gazetteer of 1835 . It reports the opening of the mines in the third year of the Jiaqing period (1798) and a tax income of

\footnotetext{
7. J. YIN and E 'Ertai, Yunnan tongzhi: 30 juan, juan 11, and Ruan Yuan, Yunnan tongzhi, juan 9, op. cit.

8. Naiyong CUI 崔乃鏞, FANG Gui 方桂, and Xiaoqiang LIANG 梁晓强, Dongchuan fuzhi 東川府 誌 (Gazetteer of Dongchuan prefecture), 1761, Kunming, Yunnan renmin chuabanshe, reprint 2006; Jishan YIN and E 'Ertai, Yunnan tongzhi: 30 juan; and Y. RuAN, 阮元, Yunnan tongzhi 雲南通志 (Gazetteer of Yunnan), op. cit.
} 
289.814 liang as of the ninth year of the Daoguang period (1829). An excerpt from the Huidian shili 會典事例 (Collected statutes) on the opening of the mines is added:

\section{樂馬銀故額課短縮，附近金牛箐出有銀礦，堪以試采，作爲 樂馬子厰, 以補缺額。}

The Lema silver mines no longer fulfil their tax quota. In the vicinity silver ore was discovered at the golden ox thicket (jinniu qing 金牛箐), worthy of trial exploitation. The mines were opened as a branch mine of Lema so as to make up the shortfall in the tax payments.

The text dates the beginnings of the Jinniu mines to 1798. The statement is not entirely specific but suggests that this was the year of the official opening, following promising trial exploitations. The Lema mines were located in Zhaotong prefecture just north of Huize county in a side-valley of the Niulanjiang. The mines had been officially opened in 1767 and reportedly were the most important silver mines around $1800^{10}$. The maximum tax income collected from these mines, probably not long after the official opening in 1767 , reached 42,532 liang, while 4,674 liang were reported in $1829^{11}$. Jiniu was in fact not exactly located in the vicinity of Lema, but at a distance of about $100-140 \mathrm{~km}$ of road travel that required six to seven days of travel. The opening of Jinniu as a branch mine of Lema was evidently a measure for including the revenue with the latter so as to compensate for shortfalls.

The tax regulations were the same as for Lema:

礦價銀一兩抽課一錢五分，撒散三分。洪火一盤，抽銀一兩 二錢，燥火一盤，抽銀九錢，盡收盡解。

From each liang of silver by the mine rate, a tax of 0.15 liang, and odd charges of 0.03 liang. From each hong-smelting, 1.2 liang is

9. Y. RuAN, 阮元, Yunnan tongzhi 雲南通志 (Gazetteer of Yunnan), op. cit., p. 621.

10. A remark by Tan Cui 檀萃 (1725-1801) reflects the towering importance of Lema. He ranked these mines as the most important in the interior of the empire, presumably writing towards the end of the $18^{\text {th }}$ century. See Yuda YANG, "Silver mines in frontier zones," op. cit., p. 87.

11. Y. Ruan, 阮元, Yunnan tongzhi 雲南通志 (Gazetteer of Yunnan), op. cit, p. 620. 
raised as a tax, from each zao-smelting 0.9 liang, all to be collected and transmitted. ${ }^{12}$

Taxation tapped the silver output as well as two smelting processes. The rate of 0.15 and additional odd charges of 0.03 liang amounted to $18 \%$ of the silver output, to which unclear amounts derived from the taxation of the smelting processes have to be added. Due to our insufficient understanding of terminologies of budgeting and technology, part of the record remains unclear. "Silver by the mine rate" presumably refers to a relatively low purity standard of the silver as is left the mines, before final refining. The two steps in the extraction of silver are apparently taxed by process. The tax rate cannot be reconstructed because the loads of smelting furnaces and silver separation hearths as well as the outputs of each process are uncertain. The clear aspect of the rules is that taxation was clearly tied to the actual output.

In 1843-1844, Wu Qijun compiled the only surviving compendium of the Yunnan mining administration and the core source on mines and mining and metallurgical technologies. ${ }^{13}$ The entry on the Jinniu mines records 1795 as the year of opening, and a tax quota of 298 liang. ${ }^{14}$

The recorded year of opening in this work is three years earlier than in the provincial gazetteer, which might refer to the year when the mine was registered with the provincial mining administration. In this case, three years elapsed before reporting to the central government. The compendium unmistakeably records a fixed tax quota, which moreover is exactly congruent with the recorded tax income of 1829 . One of the records is bound to be incorrect.

A new provincial gazetteer was compiled from materials that in part go back to the Qing period and to information collected in the early Republican period. The entry on the Jinniu mines is short, simply stating that the mines were worked in the Jiaqing (1796-1820) and Daoguang (1821-1851) periods and ceased operation during the wars of the Xianfeng

12. Ibid., p. 621. We interpret one "ore fire" as the smelting of the lead-silver ores for rich lead and "dry fire" as the cupellation, each being taxed by the number of processes.

13. Q. Wu 吴其浚, Diannan kuangchan tulue 滇南矿厂图略, op. cit. An older compendium is known to have been compiled in the late $18^{\text {th }}$ century, but this work is lost.

14. Ibid., juan 2, p. 101. 
(1852-1862) period. ${ }^{15}$ According to this source, exploitation ended with the mid- $19^{\text {th }}$ century civil wars.

The provincial gazetteer of 1835 and the compendium of the mining administration reflect administrative data concerning Yunnan province that were reported to the central government and concerned the obligations of the provincial government in regular reports and revenue transfers towards Beijing. The gazetteer of the Republican period is a compendium of recorded and available information that largely follows existing format, but was compiled with the aim of providing information for modernization. In the case of the Jinniu mines, the two official Qing period records suggest a mine of middling importance that was in operation from 1795 or 1798 and certainly lasted into the 1840s. At the recorded tax rate of $18 \%$ that probably reached about $20 \%$ including the taxes per process, we may expect annual outputs of 1450 liang $(54 \mathrm{~kg})$. According the gazetteer of 1949, the duration of exploitation was from about 1796 to 1850 or some years later, lasting for over 50 years.

\section{Huang Mengju's account}

Huang Mengju 黄夢菊 (dates unknown), left excerpts from communications that he wrote during his official career in Yunnan in Factual Titbits from Yunnan. The texts that were printed in 1849 contain a section on the Jinniu mines:

縣屬之金牛銀厰距城兩站，開於乾隆五十三四年，有金牛、 天庫等硐，采獲大硔，嘉慶二三年日賣千金，系藩憲委員經 管。嘉慶四年硔砂正旺, 硐内出水, 人不能下, 無水之硐, 硔微算薄，辦者虧本，開辦水泄，久不能通，敞漸衰竭，撥 歸會澤縣管，淘塃洗燥，二十年前月尚抽收課銀七八兩，自 道光元年以後, 塃燥洗盡，硐無人辦，㩯遂停廢，而咨部額 課不能減免，每年應報銀二百八十九兩两，由縣賠解。上 年秋冬，離金老敞二十里之開倉箐路有引苗，㪣民試開槽硐 四口，内天才、鸿喜二硐微接二寸寬刷硔，夾硬難采，耆爐 一座，兩三月方能凑扯一火。抽課銀二三兩，硔質不佳，成 本虧折，現雖招丁二十餘人，能否成效，尚難逆料。又有天

15. Guangyu QIN, 秦光玉, Xinzuan yunnan tongzhi 新纂雲南通志 (Newly-compiled gazetteer of Yunnan), juan 64, p. 5. 


\section{培子凮開硐一口, 儘產鉛硔, 扯火下罩, 銀味淡薄。成本不} 敷, 現將次停歇。

The Jinniu silver mines are in the jurisdiction of this district and at a distance of two day stages. They began operations in 1788, with the Jinniu mine, the Tianku mine and others. Rich ores were extracted, selling at one-thousand liang per day in 1797 to 1798, whereupon the provincial treasurer dispatched a supervising official. When the ores were at their richest in 1799, water entered the workings, and the men could no longer descend, while the dry working possessed only thin seams of poor ores. Operators made a deficit and although they cut drainage galleries, these could not reach through. The mines went into decline and their administration returned to Huize District. Twenty years ago, the tax revenues were still some seven or eight liang, but from 1821, the excavated ores had all been treated and smelted, and as nobody worked the mines any more, they were abandoned. The tax revenue reported to the ministry, however, could not be reduced or abolished, so that the 280 to 290 liang that were reported each year had to be covered by the district government. Last autumn to winter, a seam was discovered at Cangqinglu some twenty $l i$ from the old mines. Miners opened four workings, of which the Tiancai and the Hongxi mines struck minor seams of 2 cun $[6.4 \mathrm{~cm}]$ thickness of "brushed ore". The hard rock makes extraction difficult, with some two to three months' work producing only enough to fill one furnace and generating taxes of two to three liang. The ore is inferior and costs exceed gains. Although over twenty workers were recruited, it is uncertain whether the mines will be productive. In addition, a branch mine was opened at the Tianpeizi that has only produced lead. The ore was smelted and cupellated, but contained only traces of silver. As operational costs exceed the income, operations are about to cease. ${ }^{16}$

Huang Mengju's account provides a different story from the sources investigated above. He states that operations began in 1788 and boomed for two to three years between 1797 and 1799. The peak daily outputs of

16. Mengju HuANG 黄梦菊, Diannan shishi 滇南事實 (Factual titbits from Yunnan), Yudetang, 1849, p. 33-34. 
1000 liang convert to $37 \mathrm{~kg}$, suggesting a yield of over 10 tons of silver per year. Huang's round figure may have been an overstatement, yet even a tenth of this amount documents that the ores that were extracted for a while were extremely rich. The more indirect record that through two decades after the water intrusion, exploitation continued, largely relying on ores extracted before 1799. Productivity on this scale would indeed have made Jinniu a major mine that could have had the potential of compensating the shrinking productivity of the Lema mines.

The provincial treasurer recognized this, and had the mines officially opened, implementing direct administration by an official dispatched to reside on site. In 1799, however, the deeper workings became inundated. Attempts at driving in drainage tunnels remaining unsuccessful, operations were reduced to shallow workings and to exploiting material already extracted, as well as possibly to re-smelting slags of the bonanza years. On a much reduced scale, these continued until 1821, in the end producing under $10 \mathrm{~kg}$ of silver per year.

Huang Mengju relates the more recent events from his time of writing. The relative dates are somewhat uncertain because the excerpted documents are undated. We know that he served as magistrate of Huize from 1843 to 1846 . The prospecting in the vicinity of the Jinniu mines would date between 1842 at the earliest to the mid-1840s. Two mines were opened at Cangqinglu 仓箐路 some $10 \mathrm{~km}$ from Jinniu, as well as another mine at Tianpeizi 天培子 that however was about to be abandoned. The two workings produced enough ore for a smelting only every few months and generated a tax income of two to three liang (ca. $100 \mathrm{~g})$, suggesting a total annual output of 1.5 to $3 \mathrm{~kg}$ of silver.

Huang's account suggests collapsing productivity from 1799 due to the intrusion of water, with operations on a greatly reduced scale lasting for another two decades, and trial mining in the 1840s that at the time of his writing hardly raised hope for any turn for the better. At the same time, however, Huang unmistakably states that the tax rate, whether nominally fixed or not, had to be met.

The text is excerpted from a report that the local magistrate submitted to the provincial government. It hence reflects information that was available to the provincial authorities. This information, however, is in contradiction to records on the same mines printed by the provincial and central 
governments and concerning the in the fully official documents recorded at the level of the central government. The contradiction suggests that either the fully official records were far removed from actual conditions and are hence largely useless to historical research, or that local governments were extraordinarily inventive at constructing reasons why they were unable to meet tax demands, especially when these were rates that they had to forward to the central government. As the issue cannot be resolved on the basis of the few available written sources, the authors attempted the establish historical exploitation using remains on site and oral histories passed down in the mining villages.

\section{The fieldwork}

The localization of the Jinniu mines at two days travel from Huize city was relatively straightforward. First inquiries at Huize yielded no knowledge of silver mines by this name. The Republican ordnance maps, however, show a market village names by the name in the south of the district, and Jinniu village still exists today. From 12-13 November 2016, Nanny Kim visited Jinniu together with Yu Hua, Zhang Yemei, and Deng Zhicheng of the History Department of Yunnan University. ${ }^{17}$ Jinniu village in fact was the site of the Jinniu mines.

The village is located on the southeastern slopes of the Guniuzhai 姑牛寨 mountain massif that rises to about $4100 \mathrm{~m}$ between the Huize plateau and the valley of the Yilihe at about $2000 \mathrm{~m}$ and the Xiaojiang valley at only $1000 \mathrm{~m}$. The village is situated on a low tongue at the confluence of the Mieze 咩则 river with the Qingshui 清水 river, a stream that descends southwards from the main mountain massif. The Mieze flows in a tectonic valley that extends across the southern part of Huize, running east/northeast to south/southwest. At Jiunniu village, the valley bottom is at about $2300 \mathrm{~m}$, with the flat southern peaks of Guniuzhai towering above. The geography of the area is shown in Fig. 1 and 2.

17. At the time of the visit, Hua Yu 余华 was a PhD candidate; Zhang Yemei 张叶梅 and Deng Zhicheng 邓智成 were graduate students. 


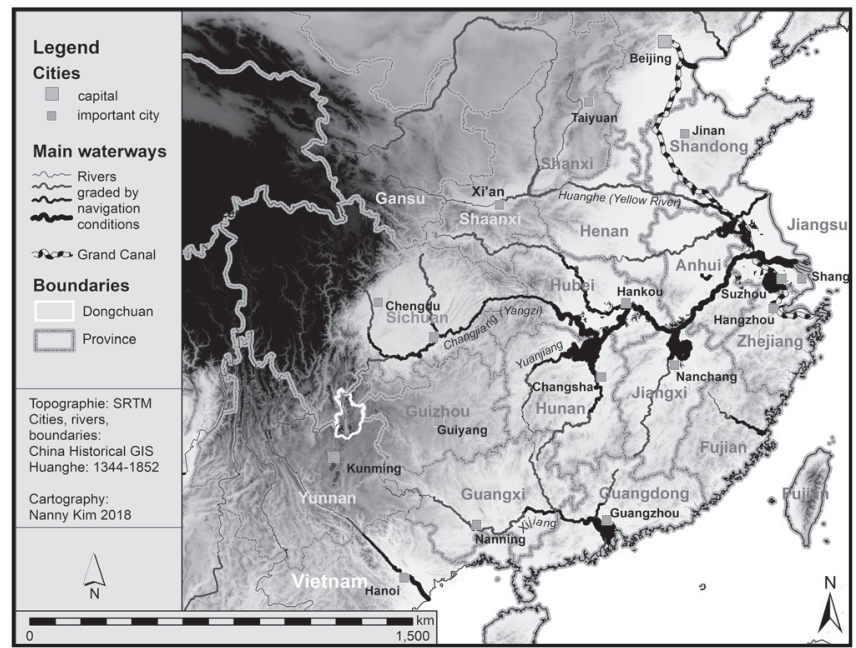

\section{Fig. 1. - Donchuan prefecture in northeastern Yunnan}

Cartography Nanny Kim 2018

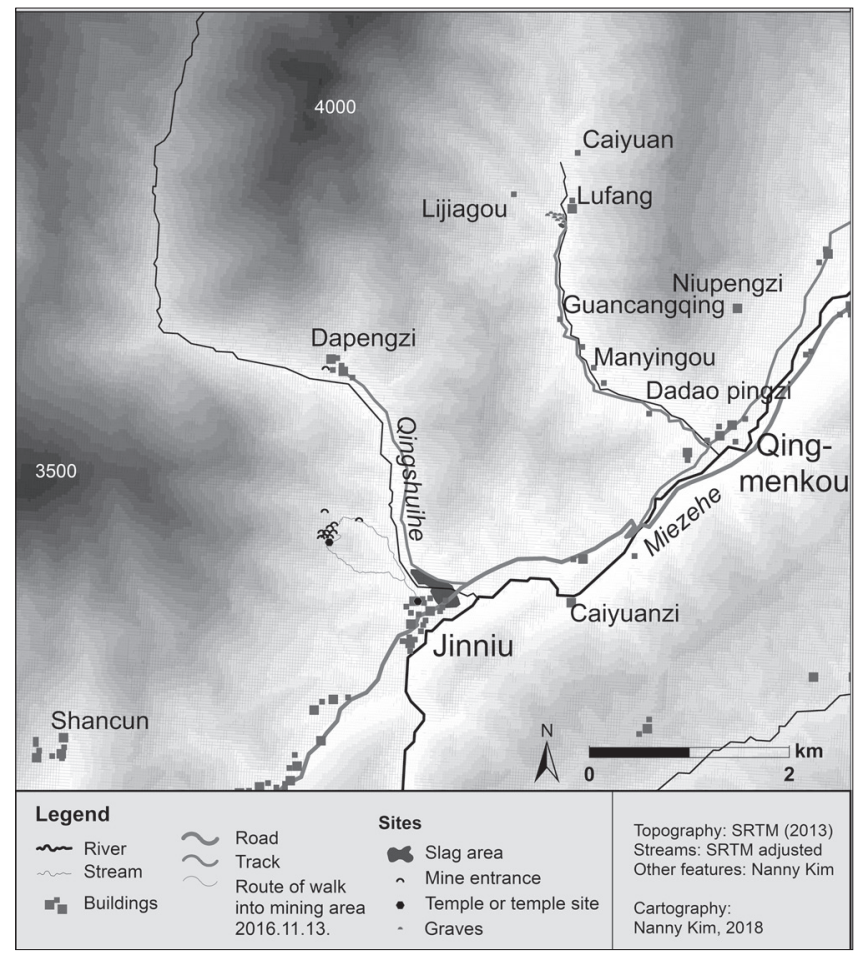

Fig. 2. - The remains in and around Jinniu

Cartography Nanny Kim 2018 
The key informant who related the oral history concerning the mines and guided us to the sites of mining and smelting was Mr. Xu Donghai 徐东 海 (63 years old, a native of Jinniu). His family had been resident in Jinniu for four generations and formerly lived in Daibu 待补. At the time of his ancestors' arrival the mines were no longer exploited.

Local oral traditions still identified several sites with the mines, including named mine entrances, and relatively level sections on the nearby ridges associated with a temple, a market and living quarters of miners. There is also a site called “official's house” (guanfang 官房) a short way up just behind the village, without remains of buildings. The name supports Huang Mengju's statement that the provincial treasurer dispatched a resident to the Jinniu mines.

According to $\mathrm{Mr}$. $\mathrm{Xu}$, there was a saying that there used to be 18 furnaces at work and that 28 tables were set up at mealtimes. The numbers evidently cannot be verified. As the tradition does not employ the standard numbers in the range, which would be multiples of 10,36 , or 48 , however, they may reflect a specific memory of a period of productivity, but not of 124 a large mine.

A local story on the founding of the mines identifies the founding mine boss as Xiao Fu 萧富, relating that he and his men started digging, but hit no ore for eight days. When they were about to give up, a man from Xuanwei 宣威 came by and told them that they would have to dig for another six days. By the end of the fifth day they were the verge of giving up, but on the sixth day they actually hit on ore. Later on, they got the man from Xuanwei to come back to Jinniu, and where he directed them to dig, they would find ore. He stayed for some ten years, but later returned to a mine in his home area and the Jinniu mines soon entered into decline. Oral histories at numerous mines contain the element of a person, often beggar-like, who travels by and tells the mines where and when they will strike lucky. Moreover, several foundation stories of mines in north-eastern Yunnan are linked to men from Xuanwei ${ }^{18}$. It appears that the mines of Xuanwei, an area with old, small-scale mining on the main road from Central and Eastern China, in fact played a role in the expansion of mining into north-eastern Yunnan. The name of the founder, however, is specific

18. Fieldwork by Nanny Kıм, Xiaocen Li and Peifeng Liu on two silver-zinc mines in Yiliang and a zinc mine in Qiaojia, October 2017. 
to Jinniu. The memory that combines specific and generic elements reflects a history that has not yet passed out of living memory. Beginnings some two centuries ago fit relatively well with the oral tradition.

There was a small Temple of the Western Peak (Xiyue 西岳, i.e. Hengshan in Hunan) on the present-day market street of the village. The name of the temple indicated a community of in-migrants hailing from Hunan. The small size of the present building does not suggest a large or wealthy community. As the key could not be found during out stay, we could not enter the courtyard and have a closer look at the age of the buildings. Several informants confirmed that there were no stone inscriptions. The location of the temple in the centre of present-day village suggests that the village area has been largely stable.

The smelting site is well known locally, as the ground used to be covered in a thick layer of slags just below the village. The area extends under the recent building below the older part of the village and across the low-lying fields on the northern bank of the Qingshui river (Fig. 3). The villagers sold slags for their lead content for several years during the 1990s, but slags and sections of the ceramic grids used in traditional cupellation furnaces are still easily found in the fields and in the stream.

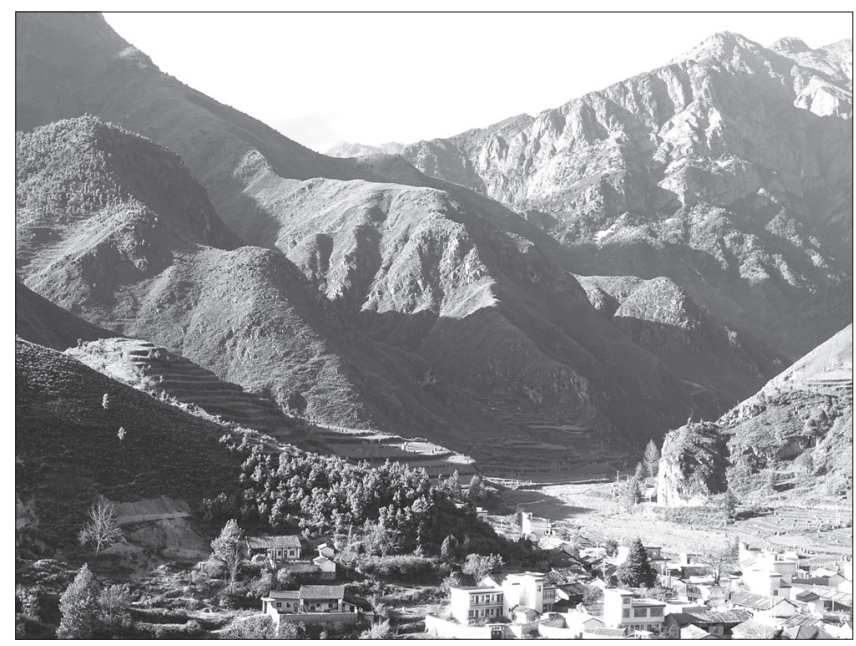

Fig. 3. - The northern part of Jinniu village with the lower end of the Qingshuihe valley seen from across the Miezehe

The mining area is on the slope behind the bare ridge in the middle of the photo. 
The main mining area is an hour's way up a western side-valley of the Qingshui river (Fig. 4). Six mine entrances in a bowl-shaped valley facing north are locally known as the Jinniu mines. The path leading to the bottom end of the bowl is a visibly built structure on its steepest section, zig-zagging up next to the small stream that descends in falls. The slope was covered in terraces that had been potato fields but were now used for grazing cattle and goats. Mr. Xu explained that there was a mine entrance entering the ridge on its northern flank that was larger in diameter and called Xieshuidong 泄水洞 (literally “water-draining hole”).

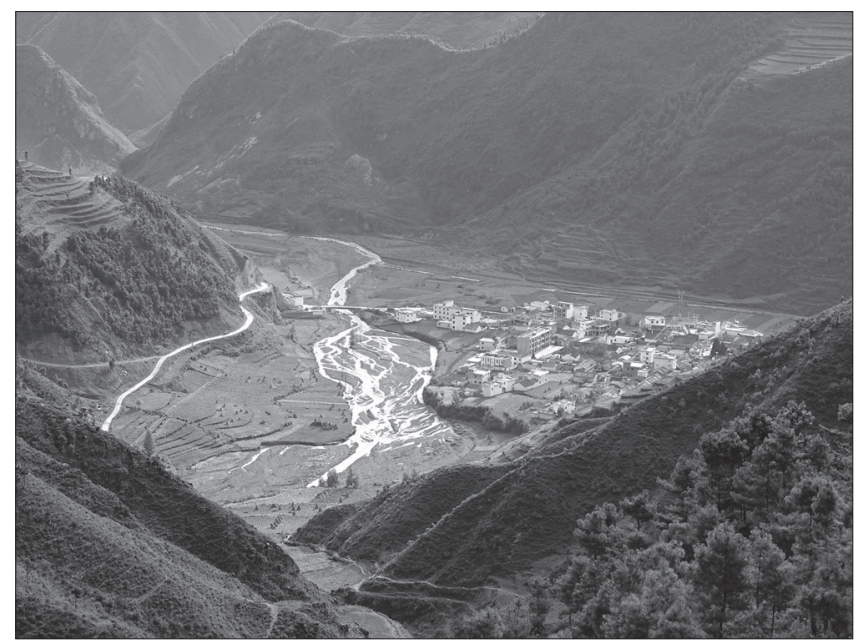

Fig. 4. - View from the old road from the village to the mining area onto the confluence of the Qingshuihe and the Miezehe

The historic smelting area comprises the level area of fields to the left, the wider, meandering section of the stream the new buildings at the lower end of the village.

\section{Photo Nanny Kim 2016}

The mine mouths that we saw were partly filled with water and entered the mountain horizontally. They were distributed on the northwestern slope between about 1400 and $1600 \mathrm{~m}$. With heights of about $1.5 \mathrm{~m}$ and widths of about 1.5-2 m, they appeared relatively large for historic workings. Re-exploitation had been attempted unsuccessfully in recent decades, possibly changing the entrances. 
We walked up to the ridge at about $2600 \mathrm{~m}$. Mr. Xu pointed out two flat sections on the higher ridge to the north and told us that they were called Dayingpan 大营盘 (large camp) and Xiaoyingpan 大营盘 (small camp) and that according to local tradition the larger used to be the market village for the miners and the smaller the housing area.

At the southern upper rim of the bowl, the ridge forms a grassy saddle before joining the mountain flank (Fig. 5). Mr. Xu told us that this used to the site of a large temple, and the starting point of the road on which mules used to carry the ore down to Jinniu. The track is still visible in places, with a width of about $1.5-2 \mathrm{~m}$, built or cut in the rock in a few places.

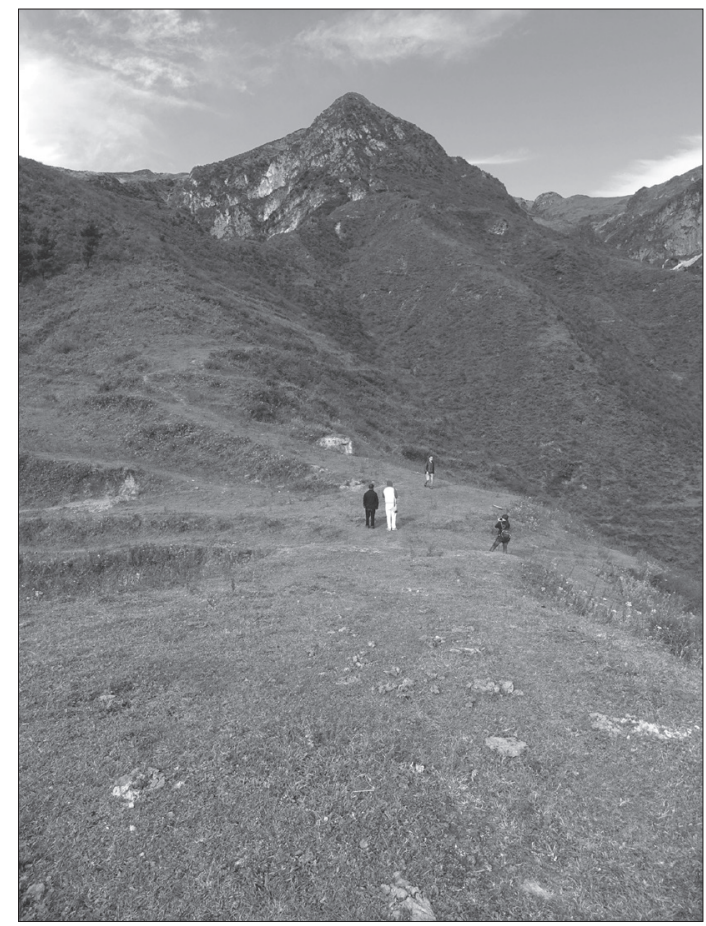

Fig. 5. - The saddle between the mining slope and the descent towards the village, site of an old temple

The mountain flank to the right is the upper end of the mining slope. The peak is a protrusion of one of the lower ridges of the Guniuzhaishan, at about $3500 \mathrm{~m}$. 
The mountain flank above this valley also displays some workings, which are known as the Luomadong 骡马洞 (mule mines). It is uncertain whether these were trial workings or actual mines.

We were also told about a single large working at Dapengzi 大棚子 (big shed), about an hour's walk up the Qingshui river valley. The village was inhabited by about 40 families, and there were no slags on that site.

Several place names in the next northern side-valley of the Mieze river were suggestive of silver mining, such as Manyingou 蛮银沟 (barbarian silver valley), Guancangqing 官仓箐 (official granary thicket), Liufang 六 房 (six houses) or possibly Lufang 炉房 (furnace house), and Caiyuan 菜 园 (vegetable garden). It moreover seemed possible that Guancangqing was the Cangqinglu, which means "granary thicket road", that appeared in Huang Mengju's account. Our informants at Jinniu had never heard about historic mines in that valley.

With some time left in the afternoon, we walked into the very narrow valley for approximately $4 \mathrm{~km}$. A track had been built that was passable for small tractors and the tiny villages were partly or entirely abandoned. We ended up just below Lufang, the only slightly larger village near a bifurcation in the valley, meeting only a handful of people. Several elderly inhabitants whom we asked along the way vaguely confirmed that old mines existed somewhere. Eventually we were told that there were some slags right next to a few old graves right next to the track. The spot was easy to find near the mouth of a small brook descending in an eastern side-valley. None of the graves had legible inscriptions, but some appeared to be still looked after. There were some ten graves that had kept their shape and some more that were mostly eroded (Fig. 6). The slags were found in near the brook only. With the bottom end cut through by the track and the erosion caused by summer high waters in the stream, the extent of the slag area could not be fully established. It is overall small, not over 20 x $10 \mathrm{~m}$. Walking a bit further on we met a friendly old gentleman, who told us that he was 75 years old and lived in Lufang, the last village in the valley and just in sight. His family had moved to Lufang five generations ago. He stated that Caiyuan was the village highest up in the, but there were only two families left. The track had been built some years ago, when a company was preparing to start a mine. They had driven in two mining 
galleries in the slopes just above the bifurcation of the valley near Lufang, but the venture was unsuccessful ${ }^{19}$.

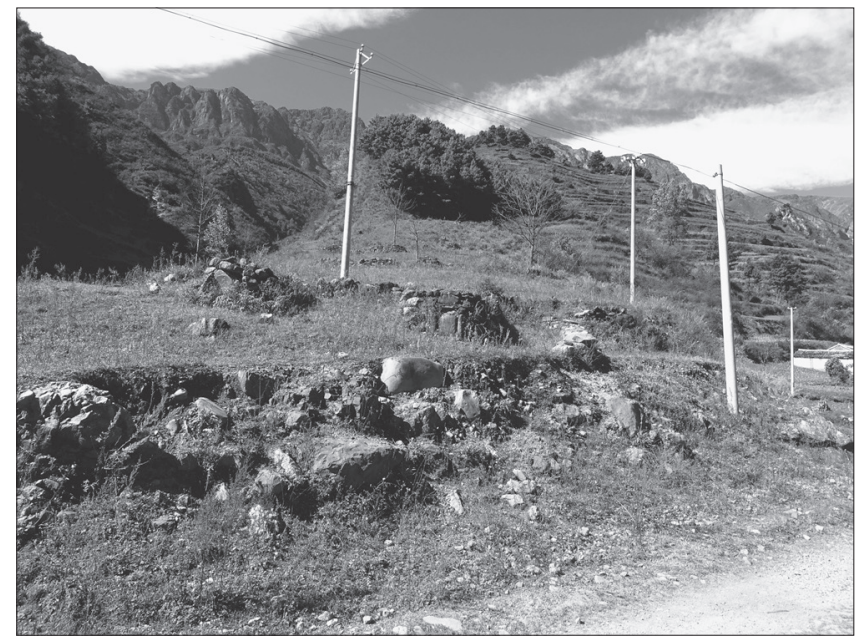

\section{Fig. 6. - The graves and the smelting site near Lufang}

The ridge in the background separates the valley of the Qingshuihe and the Lufang valley.

\section{Photo Nanny Kim 2016}

The fieldwork at Jinniu provided a good picture of the layout and the scope of the mines. There were six to eight mine entrances in the main mining area of the bowl-shaped slope, three on the continuation of the slope into the valley above Jinniu, the drain mine on the ridge to the north, one or two in the side-valley below, and one near Dapengzi. The smelting site occupies roughly 50,000 square meters, corresponding fairly well with the mining site. The mining remains are evidence of sizeable exploitation but not on a major scale or over an extended period.

The findings confirm Huang Mengju's account. The mining and smelting sites of Jinniu document exploitation over a period on significant but not on a major scale and the local tradition of Jinniu clearly records and end of mining before the $19^{\text {th }}$ century civil wars. On account of the absence of slags near Dapengzi, the site can be identified with Huang's Tianpeizi lead mine.

19. For the full field report with photos, see https://www.zo.uni-heidelberg.de/sinologie/research/ epm/12_jinniu_huize.pdf. 
The findings in the valley north of the Qingshuihe, specifically the small smelting site, allow a fairly certain identification the minor exploitations that Huang recorded for Cangqinglu. Huang's information on the distance from Jinniu is quite precise, while note that the mine produced ore for a smelting only every few months is supported by the remains on site, which suggest little more than trial smeltings.

In short, the fieldwork provided evidence for the reliability of Huang's account. The history of the mines thus would have been short, with successful exploitation under two decades. The inevitable conclusion is that the recorded tax rates that suggest continuous medium-scale exploitation from about 1798 into the 1840 s is misleading.

\section{Administrative layers}

If we accept Huang Mengju's account, the Jinniu mines were opened in 1788 , experienced two to three boom years and sank back to insignificance when the most productive galleries became waterlogged in 1799 . The mines were not instantly abandoned. The owners had a drainage gallery driven in, but their effort turned out unsuccessful for unknown reasons. Operations continued in some fashion down to 1821, apparently in part by smelting ores excavated before the intrusion of water. The relatively long duration also suggests that the mines above the water level continued to be exploited. The mines were left deserted in the 1820 s, with prospecting efforts in the 1840s remaining largely fruitless.

We thus learn that the "opening" of the mines in 1797 or 1798 was not related to the beginning of operations but to the decision of the provincial treasurer of making the mines his responsibility and of setting a tax quota. Similarly, the end of activities in 1821 was simply ignored in the official records, which continued to register the mines as operating. In other words, none of the basic data on taxation or the period of operation can be relied on.

At the same time, the tax quota of 298 liang $(11 \mathrm{~kg})$ remained in place and the county duly remitted this sum to the provincial government each year. The fact that the county government put up with this situation over four decades even though the tax income raised from the mines was negligible raises many questions. Where did the county magistrates raise alternative 
sources of income to cover this sum? Why was the tax quota left unadjusted? Was it the county governments that preferred not to raise the issue? Was it the provincial government who insisted on the accountable income? Was it the central government that resented change?

Huang Mengju's account adds further complications. It reveals that the local county magistrate knew with considerable precision even about an exploitation that employed twenty persons and yielded a tax income of merely two to three liang, whereas the maintenance of some twenty men who were reportedly hired for the trial exploitations consumed considerable sums.

By this token, we have reason to believe that 1788 was in fact the year when exploitations turned from modest to attractive yields. There is also no doubt that the county government was perfectly aware of the reason why the provincial treasury re-assigned the administration of the Jinniu mines to Huize county at some point around 1799 , namely that the outputs fallen off without much prospect of recovering. In other words, the county government took over a tax responsibility in full knowledge that the associated mine contributed little to fulfilling it. Moreover, as Huang's account is excerpted from a communication with the provincial government, we furthermore know that the provincial government was also informed of this.

The entire arrangement appears incomprehensible, yet all layers of government kept up appearances and payments for over four decades. The analysis of this entanglement requires the consideration of the interests and options of the players involved, as well as the layers of financial obligations. From the top to the bottom, the players were the central government, the provincial government, the local government and the mining entrepreneurs. The final group was evidently crucial, if only indirectly reflected in the available sources.

The inflexibility was most pronounced in the top level. Huang stated that "[ $\mathrm{t}]$ he tax revenue reported to the ministry, however, could not be reduced or abolished, so that the 280-290 liang that were reported each year had to be covered by the district government". For some reason, the conditions reported to and approved by the Ministry of Finance ( $h u b u$ 戶部) became inflexible. We gather that the reason for this inflexibility was inbuilt in the system that required memorials to the throne and an imperial decision 
in such matters. It was also a consequence of the financial system that defined budgets by revenue and permanently fixed certain revenues to certain expenses. Hence, any adjustment in revenue regulations had consequences for budgeting.

The identification of the records on mining taxes in government records as the fully official regulations by the central government implies that the provincial and local administrations were in possession of different information and operated with a different set of customary rules. These would include the customary surcharges (lougui 陃規) and provide part of the answer as to why regional and local government acquiesced to a rigidity that seemed to heavily burden them. In the case studied here, the rules of taxation recorded in the compendium of the mining administration constitute the fully official regulations. These define the tax rate that consisted of $18 \%$ of the silver output and a tax on each smelting and each cupellation process. The fully official tax that was actually collected and presumably amounted to about $20 \%$ of the silver output. On top of this, the county government certainly levied a customary surcharge. Surcharges and other local regulations were not arbitrary, but publicly announced and fixed in stele inscriptions or placards, but they never appear in the fully official documentation. We have no records of the system employed for mining surcharges ${ }^{20}$. While we expect that actual taxation reached about $20 \%$ of the outputs, we are certain that levies were never a fixed quota system for that would have created incalculable operating conditions and effectively stifled the industry.

The fixed quota, therefore, was disjointed from the actual income that the local government derived from a mine. In the case of Jinniu, the existence

20. The only account of actual taxation at a mine is recorded in Chambre de Commerce de Lyon, La Mission lyonnaise d'exploration commerciale en Chine 1895-1897, Lyon, A. Rey et Compagnie, 1898, p. 293. M. Duclos of the delegation of the Chambre de Commerce de Lyon visited several mines in 1896 and recorded a system of weighted scales at the Sanjia copper mines in central Yunnan. The agent of the provincial mining administration resident at the mine bought up the entire output, using a scale rated at heavier than the standard jin of $0.598 \mathrm{~kg}$, and forwarded the metal to the provincial capital still at a weight unit $10 \%$ above the standard jin, where the metal was sold at the standard jin. Because the system is unlikely to have been a recent invention in the declining years of the industry and since "tampering with scales" is mentioned in 1724, it appears probable that surcharges were levied in a comparable system. See Hans Ulrich Vogel, "Chinese Central Monetary Policy and the Yunnan Copper Mining Industry in the Early Qing (1644-1800)”, PhD, University of Zürich, 1983, revised 1989, p. 295. 
of the mines evidently was known from 1788, a decade before the official opening. It would have been operated with the permission of at least the local and probably the provincial government. Taxes were paid and shared between local and provincial government. Until the treasurer decided to take direct control, however, its existence was not reported to the centre. During the years of peak productivity, we can be certain that the provincial treasury levied sums certainly of several thousand, and possibly of several 10,000 liang. Afterwards, the county had to remit the fixed quota, although the actual income fell off quickly.

The dual system at all levels of government meant that customary tax incomes were in fact considerably above the fully official and regularized taxation. We therefore may expect that the Huize local government had sufficient alternative resources to cover the 298 liang without much difficulty. In this case, the annual extra payment was probably less trouble than reporting the problems of the Jinniu mines and lobbying for a formal closure. Similar considerations may have prevailed with the provincial government.

In the case of Huize County, however, there were additional aspects. The Jinniu mines were not the only silver mines in the county. Huize county constituted at least two thirds of Dongchuan prefecture, which was famous for its copper mines. In addition, there were silver mines in the westernmost part of the prefecture and a cluster of lead-silver and zinc mines in the eastern part of Huize (Fig. 7). 


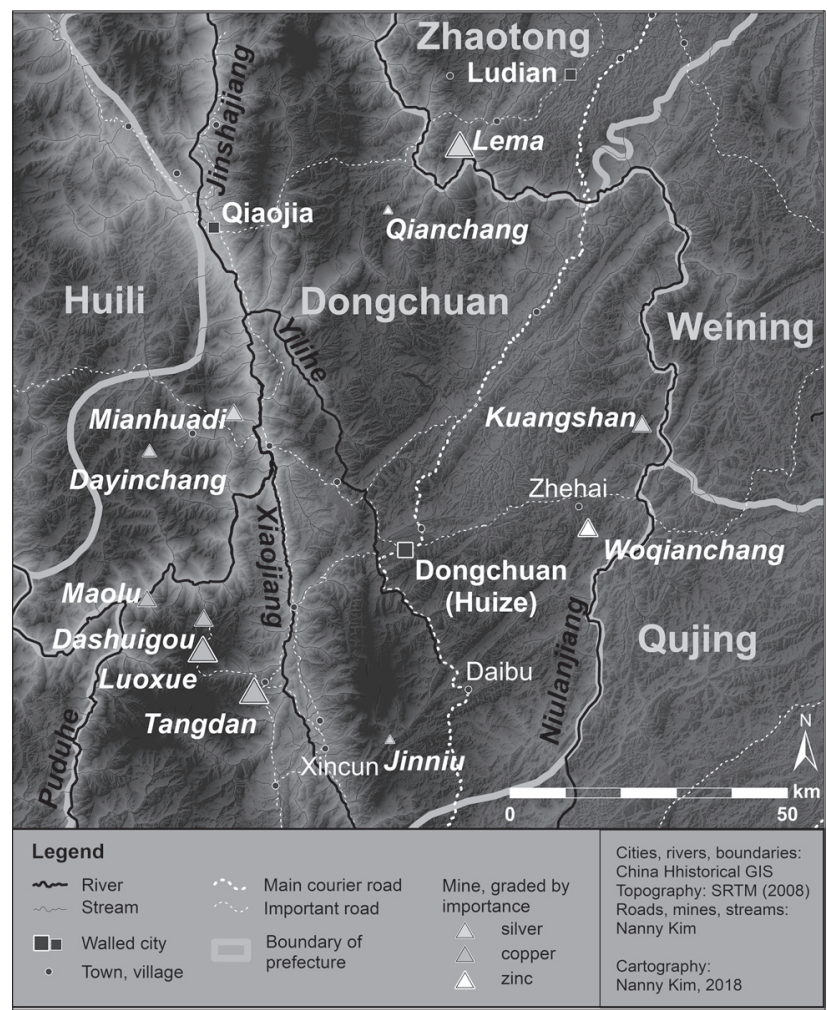

Fig. 7. - The mines of Dongchuan prefecture Cartography Nanny Kim 2018

\section{Other silver mines in Huize county}

Two more silver mines located in Huize county appear in the records. According to the compendium of 1844 , the Jiaolin 角麟 mines were opened in 1796, without a fixed tax quota. In 1819, the Kuangshan 鑛 山 mines were opened just east of the existing Jiaolin mines as a branch mine of the Mianhuadi 棉花地 mines, which were no longer able to fulfil their tax quota of 5,106 liang ${ }^{21}$. Both mines are also listed in the provincial

21. Q. Wu, 吴其浚, Diannan kuangchan tulue 滇南矿厂图略, op. cit., p.101-104. The Mianhuadi mines were located west of the Jinshajiang in Qiaojia sub-prefecture. 
gazetteer of 1949, but none appears in the last Qing edition of $1835^{22}$. According to the fully official records, both sites were unimportant.

Huang Mengju, whose account we are now inclined to treat as reliable, relates the history of the Jiaolin mines. According to his account, three mines were opened here in 1771 , on the mountain ridge just east of the Kuangshan mines. Initially, zinc ores were worked, but after striking on silver ores, the administration was taken over by a resident official in the early Jiaqing period. The silver-bearing seams became exhausted some years later, while zinc ores continued to be worked. In 1821, two mines named Yuguo 裕国 (state prosperity) and Baoxing 寶興 (abundant treasure), which were on the slope that faced south and struck silver ore deep inside the mountain, whereupon Dongchuan prefecture re-named this site Hongshan 硔山 mines and took over the administration. The prefecture used the tax income of these mines to compensate the shortfall of the Mianhuadi mines. The remaining Jiaolin mines on the slope facing northwards produced zinc ore only. Following the setting up of a resident at the mines, however, a tax quota of 160 to 170 liang had been reported to the ministry, which became immutable. Hence, the prefecture provided this sum from the tax income of the Hongshan mines, while Huize county continued to report the tax and remitted $\mathrm{it}^{23}$.

As in the case of the Jinniu mines, Huang's account reveals the incompleteness of the fully official records. He relates that exploitation began over two decades before the official opening, that the official opening was the result of sending a resident to collect taxes when the mines became productive, and that with the official reporting of the existence of the mines a tax quota was laid down that became fixed. We also learn that the Mianhuadi mines caused similar problems. With a tax quota of over 5000 liang and administrated by the prefecture, the problems presumably were correspondingly larger. The prefectural government took over two mines that became productive from the 1820s, leaving the Jiaolin mines as a lesser zinc mine. We may suspect a similar situation with the nearby Kuangshan mines.

22. G. QIN, 秦光玉, Xinzuan yunnan tongzhi 新纂雲南通志 (Newly-compiled gazetteer of Yunnan), juan 64,5 a \& 5 b.

23. M. HuANG, 黄梦菊, Diannan shishi 滇南事實 (Factual titbits from Yunnan), op. cit., p. 34. 
Remains on site, however, tell a different story. A field trip to the site in August 2014 established the main site of historic workings on ridge to the west of the main ridge between the Zhehai 者海 plateau and the valley of the Niulan river. No old workings could be seen, as the ore-bearing section of the ridge has been removed in open-pit mining. To the east of this site, mines known by the name of Qilin 麒麟 on the slope high above the river a still known and now again exploited site on the eastern slope. The name Qilin and Jiaolin, both translatable as "unicorn", are similar enough to identify the same site.

According to M. Gui Shengfu 桂胜负, a local of Kuangshan town and manager at the mining company, the valley from the mines down to the Zhehai plateau used to be filled in a massive layer of slags for several kilometres and reaching a depth of up to ten meters ${ }^{24}$. Moreover, a huge zinc smelting dump is located at Woqianchang 倭鉛故 (literally "zinc smelter" or "zinc mine") about $17 \mathrm{~km}$ south of Zhehai. According to Wu Qijun and local oral tradition, the ores came from the Kuangshan mines. In fact, as zinc distillation commonly used coal and historic coal mines existed another $15 \mathrm{~km}$ further south, the site was certainly chosen for transport reasons. The remains still visible or traceable in 2014 are shown in Fig. 8. 


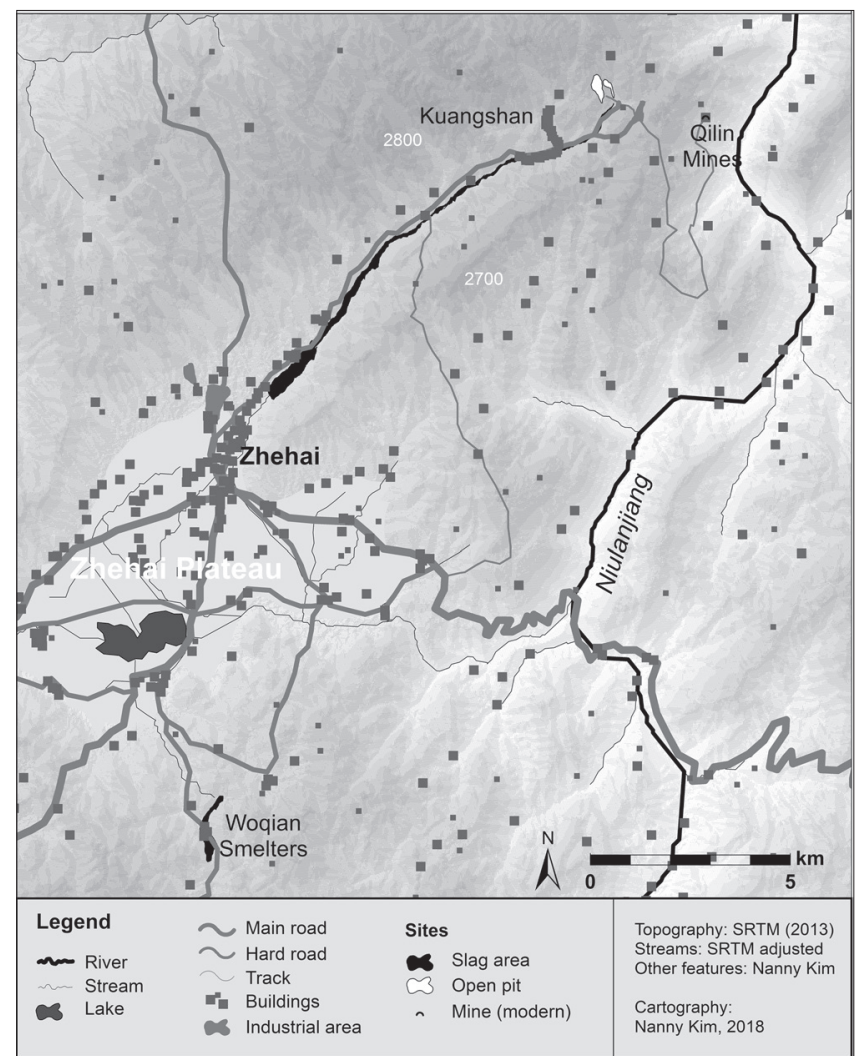

\section{Fig. 8. - The Kuangshan Mines}

\section{Cartography Nanny Kim 2018}

Yamaguchi Yoshikatsu (dates unknown), a mining engineer, was hired by the Yunnan provincial government to prepare the modernization of the mines of Dongchuan and visited the Kuangshan mines in 1912. His report states that the history of the mines could not be established but probably reached back to the Ming (1368-1644) period. He also describes the old mining centre of Kuangshan as riddled with workings and evident traces of open pit mining, records the Yuguo and the Baoxing mines as the deepest workings, noted that the silver content of ores of the Qilin mines was higher than of the ores worked at Kuangshan, and confirms the exploitation of both zinc and galena ores ${ }^{25}$. The enormous slag dumps are

25. YoshikatsuYAMAGUCHI 山口義勝, Diaocha dongchuan ge kuangshan baogaoshu 調查東川各礦 山報告書 (Investigation report of the mines of Dongchuan), Kunming, Yunnan provincial government, 1912, p. 96-108. 
unmistakable evidence of the exploitation of lead-silver and zinc ores on a large scale and over a long period of time.

The zinc exploitation, referred to as the Zhehai mines, appears in the records. These mines or smelters were officially opened in 1737 in the context of the setting up of a mint at Huize, then the prefectural seat of Dongchuan. In the same context, relatively minor lead mines at Anaduo 阿那朵 are mentioned ${ }^{26}$. No place of this name is known today or recorded on a historic map.

The productivity of the zinc smelters is indirectly reflected in the production quota of the Dongchuan mint of the mid- $18^{\text {th }}$ century, which converts to at least 350 tons of zinc required per year ${ }^{27}$. The output of the Zhehai smelters was considerable. Since zinc and galena ores occurred together, there is no doubt that the Kuangshan mines were in existence and worked on a significant scale by the mid- $18^{\text {th }}$ century. Even Yamaguchi's surmised beginnings in the Ming period cannot be ruled out as impossible. Both zinc and lead were cheap metals, and metallic lead was banned from commerce in Yunnan as a potentially military good. There is therefore no doubt that the Kuangshan mines were begun as silver mines and that exploitation required a minimum content of silver to remain viable.

In other words, the local governments successfully kept a very important silver mine off the official record for near a century, only to officially open them as an undistinguished branch mine of Mianhuadi in 1819. It would appear that the prefectural and county governments, which were both based in Huize city, were more interested in keeping Kuangshan off the record than in removing the two short-lived mines from the ministry list, at the conceivable risk of and possibly attracting closer scrutiny.

26. Q. WU, 吴其浚, Diannan kuangchan tulue 滇南矿厂图略, op. cit., p. 102, 108-109.

27. N. Cur et al., Dongchuan fuzhi 東川府誌 (Gazetteer of Dongchuan prefecture), op. cit., p.275, records a production quota of 224,000 strings. At a slightly underweight rate of $4 \mathrm{~g}$ per coin and a zinc content of $40 \%$, the mint would annually consume $358 \mathrm{t}$ of zinc. An output of over $400 \mathrm{t}$ for the mid- $18^{\text {th }}$ century is confirmed in a document quoted in Qingdai de kuangye, see Zhongguo renmin daxue qingshi yanjiusuo 中國人民大學清史研究所, and Dang'anxi zhongguo zhengzhi zhidushi jiaoyanshi 檔案系中國政治制度史教研室, Qingdai de kuangye 清代的礦業, Beijing, Zhonghua shuju, 1983, p.344, that reports a total output of 522 tons for the year 1750 . 


\section{Conclusion}

The result of the investigation of sources, remains and oral histories is devastating for the fully official records and dampening for source-based research on Qing period mines. It has shown that local governments knew in detail about operations in their areas, but that the information that reached the central government and was subsequently laid down in the fully official records diverged massively. In the case of the Jinniu mines, we have been able to disentangle the layers of information with the help of fieldwork and due to the surviving account by a well-informed local official. The unravelling has shown that remains and oral traditions provide key information, even 150 years after the end of exploitation. At the same time, in the case of sites for which the official record is the only source, fieldwork becomes the most importance source, yet assessments remain beset with uncertainties.

\section{Authors}

Nanny Kim is a researcher at the Chinese Studies Institute, Heidelberg University. She uses historical and geographical methodologies in her researches about transportation systems, people's mobility, mining and landscapes transformation. Her current research project on silver mining is funded by German Research Foundation and can be looked up at: http://www.zo.uni-heidelberg.de/sinologie/ research/epm/.Contact: Nanny.kim@zo.uni.heidelberg.de

Yuda Yang is a professor at the Historical geography Institute of China, Fudan University, Shanghai. His research interests include history of climatology, the history of South West China frontiers regions and silver mining in the same regions. This research was made possible with funding by the Ministry of Education of China (Project No.13JYA770041).Contact: Yudayang968@sina.com 